\title{
Świadek wykluczenia w sytuacji bullyingu. Predyktory interwencji
}

\begin{abstract}
STRESZCZENIE
Świadek bullyingu odgrywa istotną rolę w procesie dręczenia. W badaniach naukowych coraz częściej można zauważyć, że nie koncentrują się one jedynie na diadzie uczestników dręczenia - sprawcach i ofiarach, a włączają w cały proces również świadków. Obserwatorzy przez swoje działania mogą przyczyniać się do wykluczenia ofiar z grupy rówieśników bądź przez jawne lub niejawne sprzeciwianie się bullyingowi powodować ponowne włączanie ofiar do społeczności szkolnej.

Artykuł odwołuje się do badań własnych, które dotyczą przeszłych doświadczeń świadków w sytuacji dręczenia rówieśniczego, uwzględniając znaczenie podejmowanych przez nich interwencji w sytuacji wykluczania uczniów z grupy rówieśniczej.

Materiał badawczy stanowią wywiady pogłębione przeprowadzone z 23 studentami różnych kierunków studiów, w przedziale wiekowym 20-41 lat. Odnosiły się one do przeszłych doświadczeń z czasów szkolnych w roli świadka dręczenia. Jako cel badań uczyniono identyfikację czynników motywujących do podejmowania działań interwencyjnych w sytuacji dręczenia rówieśniczego.
\end{abstract}

\section{Słowa kluczowe:}

świadek bullyingu, bullying/dręczenie rówieśnicze, predyktory interwencji

${ }^{1}$ Karolina Walczak-Człapińska, Wydział Nauk o Wychowaniu, Uniwersytet Łódzki, Polska, e-mail: karolina.walczak@uni.lodz.pl 


\begin{abstract}
Bystander plays an important role in the process of bullying. In the researches it can be noticed that they no longer concentrate only on the diad of participants of bullying - perpetrators and victims, but we include bystanders in the whole process. Observers, through their actions, may contribute to the exclusion victims of peer group, or by explicit or implicit opposition to bullying, cause re-inclusion of victims into the school community.

The article refers own research which relates to past experiences of bystenders in the situation of bullying, taking into account the significance of their interventions in the situation of exclusion of students from the peer group.

The research material was in depth interviews conducted with 23 students aged 20-41 years, various fields of study. They referred to the past experiences of school times as a bystander to bullying. The purpose of the research was to identify the factors that motivate observes to interventions in bullying situation.
\end{abstract}

\title{
Keywords:
}

bystander, bullying, predictors of interventions

\section{WPROWADZENIE}

Problematyka wykluczenia w kontekście środowiska szkolnego jest zagadnieniem obszernie podejmowanym w literaturze przedmiotu (Wilczyńska, 2013, 2014; Wójcik, Hełka, Kozak, Błońska, Garbaciuk, Małczak, 2015; Szczurek-Boruta, Jas, 2017). Obecnie termin wykluczenie kojarzy się już nie tylko z osobami niedostosowanymi społecznie czy niepełnosprawnymi, ale coraz częściej odnosi się do jednostek w jakiś sposób pozbawionych możliwości pełnego uczestnictwa w społeczeństwie. Jak podaje Wilczyńska (2013, s. 14): „wykluczenie społeczne odnosi się zazwyczaj do sytuacji, w których ludzie mają ograniczony dostęp do praw, zasobów i możliwości, na ogół dostępnych innym członkom społeczeństwa”. Wykluczeniu społecznemu mogą być poddane zarówno grupy społeczne, jak i jednostki, a przyczyny marginalizacji mogą być różnorodne.

W odniesieniu do środowiska szkolnego wykluczenie rozumiane jest jako „odsunięcie ucznia od interakcji zachodzących między pozostałymi członkami grupy, co przyczynia się do negatywnego wpływu na jego funkcjonowanie teraźniejsze i przyszłe” (Wójcik i in., 2015, s. 124). Wykluczenie jest tu traktowane jako forma bullyingu relacyjnego, polegającego na izolowaniu, unikaniu kontaktu z ofiarą, ignorowaniu jej obecności czy sprzysięganiu się przeciw komuś. 
W literaturze (rodzimej i obcojęzycznej) funkcjonuje obecnie różnorodność terminologiczna i definicyjna opisująca dręczenie rówieśnicze. Wśród najczęściej używanych terminów obcojęzycznych znajdzie się bullying i mobbing. Terminy te stosowane są także wśród polskich badaczy problemu, ponieważ brak jest ich polskiego odpowiednika, który precyzyjnie opisywałby zjawisko.

Pojęcie bullying wprowadzone zostało przez szwedzkiego badacza Dana Olweusa (2003). Autor podkreśla w definicji trzy istotne wymiary bullyingu: nierównowagę sił między sprawcą i ofiarą (rozumianą jako przewagę psychiczną lub fizyczną sprawcy nad ofiarą), powtarzalność działań (wielokrotne powielanie zachowań atakujących osobę lub grupę) oraz intencjonalność (rozumianą jako celowe krzywdzenie ofiary, co prowadzi do korzyści, jakie zyskuje sprawca). Zaistnienie tych trzech wskaźników jest szczególnie istotne dla określenia zachowania jako bullying.

Twemlow i Sacco dokonali zestawienia dwóch spojrzeń na bullying, podkreślając istotną rolę uczestników dręczenia. Zwrócili uwagę na triadę - sprawca-ofiara-świadek. Podają, iż w tradycyjnym podejściu do bullyingu nacisk położono na relację między sprawcą i ofiarą, opisując bullying jako ,powtarzające się narażenie osoby lub grupy osób na wyrządzanie krzywdy przez osobę lub grupę sprawców, mające na celu uzyskanie przez nich nagrody (np. w postaci uznania społecznego). Ofierze trudno jest się obronić przed dręczeniem, gdyż relacja ta charakteryzuje się nierównowagą sił między uczestnikami - sprawca jest silniejszy, a ofiara słabsza” (Twemlow, Sacco, 2013, s. 291). Współczesne podejście podkreśla istotne znaczenie świadków w triadzie uczestników bullyingu, który definiowany jest w tym ujęciu jako: „powtarzające się narażanie osoby lub grupy (ofiar) na wielokrotne krzywdzenie przez osobę lub grupę sprawców, postrzeganych jako silniejszych, wzmacniane przez czynny lub bierny udział innych osób (świadków), skomplikowane interakcje społeczne i dynamikę grupy” (Twemlow, Sacco, 2013, s. 291). Autorzy podkreślają obecnie znaczącą rolę różnych zmiennych podtrzymujących lub osłabiających bullying. Istotne znaczenie przypisują pozycji społecznej jednostki w hierarchii grupy, klimatowi społecznemu szkoły, bliskim relacjom z ofiarą lub sprawcą czy normom grupowym (Twemlow, Sacco, 2013; Tłuściak-Deliowska, 2014; Meter, Card, 2015).

Znaczenie roli świadków bullyingu podkreśla w swojej definicji także Komendant-Brodowska (2012, s. 38). Używając polskiego terminu „dręczenie szkolne”, określa je jako „systematyczne stosowanie przemocy przez agresora albo większą ich liczbę wobec relatywnie bezbronnego ucznia lub uczennicy, przy czym cały proces rozgrywa się w kontekście grupowym, a inni uczniowie są świadomi tego, co się dzieje”. Warto podkreślić, iż dręczenie szkolne nie 
odnosi się do działań odbywających się jedynie w przestrzeni szkolnej, gdyż znaczna część aktów przemocy rówieśniczej rozgrywa się w okolicach szkoły, poza nią, a także w cyberprzestrzeni. Dlatego też na potrzeby prowadzonych badań i artykułu użyty został termin „dręczenie rówieśnicze”, które jest rozumiane przez autorkę artykułu jako intencjonalne, nastawione na wyrządzenie krzywdy innym lub/i zyskanie przez sprawcę określonych korzyści (np. w postaci władzy, uznania ze strony rówieśników), powtarzalne, negatywne zachowania przemocowe, charakteryzujące się nierównowagą sił między sprawcą i ofiarą, wydarzające się w przestrzeni szkolnej lub poza nią oraz rozgrywające się zazwyczaj przy pasywnym lub aktywnym udziale obserwatorów. W powyższej definicji jest zawartych kilka istotnych zmiennych odróżniających dręczenie rówieśnicze od tradycyjnej agresji.

Warto więc zwrócić uwagę na wielokrotność aktów dręczenia. Nie jest to jednorazowe działanie, a szereg powtarzających się negatywnych zachowań sprawcy ukierunkowanych na ofiarę, co nie pozostaje obojętne jeśli zastanowimy się nad konsekwencjami dręczenia. Wielokrotność negatywnych sytuacji, na które narażona jest ofiara może prowadzić bowiem do poważniejszych skutków, a w efekcie do wtórnej wiktymizacji.

Istotnym kryterium definicyjnym jest także przewaga sprawcy nad ofiarą, która nie może w skuteczny sposób obronić się przed oprawcą. Przewaga ta niekoniecznie musi dotyczyć siły fizycznej, ale może być związana z przewagą liczebną sprawców czy choćby wysoką pozycją społeczną jaką zajmuje sprawca w grupie.

Trzecim znaczącym czynnikiem jest intencja i motywacja, jaką posiada sprawca dręczenia. Założeniem sprawcy jest umyślne wyrządzenie krzywdy innej osobie, dzięki któremu może osiągnąć zamierzony cel.

Podkreślić należy, że w dręczenie rówieśnicze zaangażowani poza ofiarą i sprawcą, pozostali członkowie społeczności szkolnej, określani jako świadkowie i obserwatorzy. Wśród tych ostatnich mam na myśli nie tylko uczniów, ale także nauczycieli, którzy swoją postawą mogą wpływać na zachowania uczestników.

\section{PODŁOŻE ZANIECHANIA DZIAŁAŃ INTERWENCYJNYCH ŚWIADKÓW DRĘCZENIA RÓWIEŚNICZEGO}

Zachowanie świadków (interwencja) jest istotne zarówno z perspektywy indywidualnej, jak i społecznej. Pierwsza z nich podkreśla, że ofiary dręczenia rówieśniczego posiadające wspierających i broniących kolegów są mniej przygnębione, odczuwają mniejszy niepokój niż ofiary, których nikt nie wspiera. Owe wsparcie 
ze strony kolegów przekłada się oczywiście na mniejszą częstotliwość dręczenia, jednak szczególnie istotny dla ofiar jest tu brak poczucia osamotnienia i poczucie więzi grupowej (Sainio, Veenstra, Huitsing, Salmivalli, 2011).

Druga perspektywa akcentuje grupowy charakter dręczenia rówieśniczego. W kontekście społecznym niezwykle ważna jest tendencja świadków do hamowania lub wzmacniania dręczenia rówieśniczego. W niektórych klasach skala dręczenia jest o wiele niższa niż w innych, co jest uwarunkowane wzmożoną obroną osób prześladowanych przez ich rówieśników. Ważną rolę w procesie minimalizowania dręczenia rówieśniczego odgrywają też nauczyciele, wykazując brak zgody na proceder dręczenia (Saarento, Kärnä, Hodges, Salmivalli, 2013). Badania dowodzą, że pozytywne i wspierające relacje w środowisku szkolnym (nauczycieli i uczniów) przyczyniają się też do wzrostu ilości zgłaszanych przez ofiary przypadków dręczenia (Eliot, Cornel, Gregory, Fan, 2010).

Warto więc zastanowić się, skąd u obserwatorów tendencja do wycofywania się i braku reakcji z ich strony, prowadzących do wzmacniania wykluczenia społecznego osób poddawanych dręczeniu. Badania pokazują, że większość uczniów zaangażowanych w zachowania przemocowe jako świadkowie nie podejmuje działań interwencyjnych, których celem byłaby obrona ofiary (Tłuściak-Deliowska, 2013; Salmivalli, 2014). Świadkowie zazwyczaj stanowią dużą grupę osób, co nie sprzyja podjęciu decyzji o obronie poszkodowanych. W sytuacji, gdy nikt z uczestniczących nie reaguje, może być to sygnał dla pozostałych uczestników, że działanie sprawcy jest tylko żartem i nie ma w nim nic złego. Nawet jeśli świadek sam ocenia negatywnie zachowanie sprawcy, trudno jest mu samodzielnie przeciwko niemu wystąpić (Salmivalli, 2010). Ponadto brak reakcji ze strony świadków jest także informacją dla dręczyciela, wskazującą, że jego działania wykluczające ofiarę są aprobowane przez innych.

Drugim powodem przyczyniającym się do zaniechania interwencji jest obawa świadków o utratę własnej pozycji w grupie oraz możliwość stania się kolejną ofiarą dręczenia rówieśniczego. Świadkowie z obawy przed własnym wykluczeniem z grupy nie stają w obronie osób pokrzywdzonych.

Istotnym czynnikiem hamującym działanie świadków jest pozycja społeczna, jaką posiada sprawca i ofiara oraz więź, jaka łączy z nimi obserwatora dręczenia rówieśniczego. Badania Thornberga, Tenenbaum, Varjas, Meyers, Jungert, Vanegas (2012) wskazują, że bliskie i przyjacielskie relacje świadka ze sprawcą oraz niechęć do ofiary przyczyniają się do braku reakcji obronnej skierowanej na ofiarę. Również moralna ocena działań sprawcy jako właściwych oraz opinia o odpowiedzialności ofiary za całą sytuację, w której się znajduje (,sama jest winna temu, co ją spotyka”), jest tu nie bez znaczenia. Takie przekonanie zdejmuje 
bowiem odpowiedzialność za dręczenie ze sprawcy, a całą winę przypisuje ofierze, co jeszcze bardziej „wtłacza” ją w rolę i poddaje ekskluzji.

Ostatnim z ważnych czynników braku reakcji ze strony świadków jest niewiedza i nieumiejętność reagowania na dręczenie oraz poczucie, że podjęte działania mogą okazać się nieskutecznie i nie przynieść zamierzonych efektów.

\section{PREDYKTORY INTERWENCJI ŚWIADKÓW DRĘCZENIA RÓWIEŚNICZEGO}

Thornberg, Tandenbaum, Varjas, Meyers, Jungert, Vanegas, (2012) w efekcie prowadzonych badań opracowali koncepcję motywacji do podejmowania przez świadków interwencji podczas bullyingu (Conceptual framework of bystander motivation to intervene in bullying situation). W zaproponowanej teorii wymieniają czynniki motywujące do podejmowania interwencji lub hamujące interwencję w sytuacji bullyingu. Wśród istotnych zmiennych podkreślają znaczenie: interpretacji zachowania jako wyrządzanie krzywdy, reakcji emocjonalnych wywołanych przez dręczenie innych, ocenę społeczną zachowania sprawcy, ocenę moralną, poczucie własnej skuteczności.

Istotnym czynnikiem motywującym do podjęcia interwencji jest „interpretacja zachowania sprawcy, jako wyrządzanie krzywdy”. Autorzy koncepcji dowodzą, że osoby obserwujące i oceniające zdarzenie jako wyrządzanie krzywdy są skłonne do podjęcia interwencji podczas dręczenia rówieśniczego. Pronk, Olthof, Goossens (2013) podają , że świadomość wyrządzanego ofierze cierpienia jest pozytywnie związana z obroną osoby dręczonej. Kontrastowo, badani, którzy zachowania sprawcy oceniali jako naturalne, żartobliwe, nie podejmowali działań obronnych wobec ofiar. Autorzy przywołanej koncepcji mówią więc o pewnego rodzaju habituacji do bullyingu, która hamuje reakcję obronną.

Drugą zaproponowaną przez badaczy kategorią jest „reakcja emocjonalna na bullying”. Okazuje się, że sytuacje bullyingowe mogą przywoływać takie emocjonalne reakcje, jak strach przed byciem ofiarą, empatię lub ekscytację. Strach przed byciem ofiarą i ekscytacja demotywuje do podjęcia interwencji i jednocześnie mobilizuje do przyjęcia biernej postawy wobec dręczenia. Z drugiej strony badania wskazują również na związek między wysokim poziomem empatii a reakcją obronną wobec ofiar dręczenia (Gini, Albiero, Benelli, Altoe, 2007; Caravita, Di Blasio Salmivalli, 2009), jednakże sama empatia jest wystarczającym warunkiem uruchamiającym interwencję (Gini, Albiero, Benelli, Altoe, 2008).

Kolejnym czynnikiem zaproponowanym w koncepcji Thornberga i in. jest „ocena społeczna sprawcy lub ofiary oraz pozycja społeczna świadka bullynigu”. 
Bliski związek i przyjacielskie relacje z osobą krzywdzoną, jak również wysoki status społeczny świadka, skłaniają go do działań obronnych wobec ofiary. Z drugiej strony zażyłe relacje przyjacielskie ze sprawcą, niska pozycja społeczna świadka oraz negatywny stosunek do ofiary przyczyniają się do biernej postawy obserwatorów.

„Moralna ocena bullyingu” to kolejny czynnik przyczyniający się do podjęcia interwencji w sytuacji dręczenia rówieśniczego. Jest ona rozumiana przez badaczy jako ocena obserwowanych zachowań w kategoriach właściwe lub niewłaściwe (dobre/złe). Związana jest ona także z przypisywaniem odpowiedzialności za dręczenie ofierze lub sprawcy. O prospołecznych zachowaniach decyduje więc przekonanie, że bullying jest zachowaniem niewłaściwym i to sprawca ponosi za niego odpowiedzialność. Osoby oceniające jego działanie negatywnie były skłonne do podjęcia interwencji. Część badanych winą za dręczenie obarczała jednak ofiary, twierdząc, że to one, poprzez swoje zachowanie, przyczyniają się do dręczenia ich, jednocześnie zdejmowali odpowiedzialność ze sprawców.

Ostatnią kategorią, wymienioną w koncepcji Thornberga i in., jest „poczucie własnej skuteczności”, opisywane przez badanych jako ocena efektywności podjętej interwencji w kontekście zaprzestania dręczeniu. Wysoki wskaźnik poczucia własnej skuteczności predysponuje do aktywnej interwencji. Niskie poczucie własnej skuteczności, przekonanie, że działanie nie przyniesie zamierzonych rezultatów, a jeszcze można nim zaszkodzić sobie, jest istotnym czynnikiem hamującym interwencję. Ponadto brak wiedzy i umiejętności dotyczących zachowania się w tej sytuacji również może przyczyniać się do zaniechania działania (Gini, Albiero, Benelli, Altoe, 2007, Thornberg, Jungert, 2017).

\section{METODOLOGIA BADAŃ}

Założeniem badaczki było zastosowanie w badaniach strategii mieszanych, które zostały po raz pierwszy użyte w badaniach trafności identyfikacji cech psychicznych prowadzonych w 1959 roku. przez Campbella i Fisk. Od początku lat 80. XX wiekustrategie mieszane wykorzystuje się do integrowania danych pozyskanych przy zastosowaniu strategii jakościowej i ilościowej. Dane jakościowe i ilościowe można umieszczać obok siebie we wspólnej bazie danych lub osobno jako wzajemne potwierdzenie (Crashwell, 2009, s. 39).

W badaniach własnych zastosowano procedury sekwencyjnego badania mieszanego. Celem tego sekwencyjnego badania z zastosowaniem metodologii mieszanej była dyrektywa metodologiczna zakładająca rekonesans badawczy (Miński, 2017). 
Istotnym aspektem badania było bowiem rozpoznanie zasadności prowadzenia badań ilościowych w kolejnych etapach projektu badawczego.

Pierwszą fazę stanowiło badanie jakościowe, którego celem była identyfikacja czynników determinujących interwencję podczas dręczenia rówieśniczego. Uwagę skoncentrowano więc na czynnikach motywujących badanych do obrony (w formie czynnej lub biernej) ofiar oraz czynnikach hamujących interwencję. Zastosowano wywiad pogłębiony, który realizuje w tym wypadku cel eksploracyjny. Powodem wstępnego gromadzenia danych jest fakt, iż problematyka interwencji świadków podczas dręczenia nie jest dobrze rozpoznana. Wyniki uzyskane w fazie jakościowej badań posłużą następnie do skonstruowania narzędzia badawczego wyłaniającego typy świadków bullyingu i sposoby ich interwencji podczas dręczenia rówieśniczego.

W artykule zaprezentowano pierwszy etap badań jakościowych zmierzających do wyjaśnienia szczególnych sytuacji społecznych, wydarzeń, ról, grup lub interakcji (Locke, Spirduoso, Silverman, 1987). Materiał empiryczny był gromadzony od lutego do kwietnia 2017 roku. W tym czasie przeprowadzono 23 wywiady pogłębione (z 18 kobietami i 5 mężczyznami) ze studentami różnych kierunków studiów Uniwersytetu Łódzkiego. W czasie ich realizacji badani byli w wieku 20-41 lat. Uczestnicy zostali pozyskani do badań na podstawie ochotniczych zgłoszeń i poinformowani o pełnej anonimizacji wywiadu oraz wyrazili zgodę na udział w badaniu. Indywidualne wywiady trwały 30 min $-1,5$ godziny. Zostały one udokumentowane $\mathrm{w}$ postaci zapisu audio, a następnie poddane transkrypcji. Przedmiotem zainteresowania podczas prowadzonych badań uczyniono przeszłe doświadczenia studentów w roli świadka bullyingu. Zamiarem badaczki było bowiem ukazanie doświadczeń studentów, odwołując się do ich wspomnień z czasów wcześniejszej edukacji szkolnej: szkoły podstawowej, gimnazjum i szkoły średniej.

Podczas grupowej analizy materiału empirycznego wyłoniono pojęcia i kategorie przyczyniające się do pogłębionego i kontekstowego spojrzenia na podejmowanie lub zaniechanie interwencji podczas bullyingu, które posłużą do tworzenia narzędzia ilościowego podczas II etapu badań.

Zebrany w tej części projektu badawczego materiał empiryczny w postaci doświadczeń studentów w roli świadka bullyingu został zestawiony z modelem, który zaproponowali: Thornberg, Tenenbaum, Varjas, Meyers, Jungert, Vanegas (2012). 


\section{REZULTATY BADAŃ}

Jak wspomniano, założeniem badań była identyfikacja czynników determinujących interwencję podczas dręczenia rówieśniczego. Wśród wyłonionych kategorii motywujących do podejmowania działań pomocowych należy wymienić: przeszłe doświadczenia świadków w roli ofiary dręczenia rówieśniczego, empatię, granice norm moralnych, bliskie relacje z ofiarą dręczenia oraz poczucie własnej skutecznośći. W zaprezentowanej poniżej analizie nie ma jednak jednoznacznych zmiennych, które decydowałyby o podjęciu działań obronnych. Można powiedzieć, że interwencja uwarunkowana jest wieloma czynnikami indywidualnymi i społecznymi, które warto uwzględnić podczas planowania kolejnych etapów badań.

\subsection{PRZESZtE DOŚWIADCZENIA W ROLI OFIARY}

Istotnym czynnikiem, który decyduje o podjęciu lub zaniechaniu interwencji podczas bullyingu, są wcześniejsze doświadczenia świadków w roli ofiary bullyingu. Jeden ze studentów, przywołując swoje doświadczenia z czasów szkolnych, wspomina o byciu ofiarą dręczenia rówieśniczego:

Kiedyś sam miałem takie problemy, a dzisiaj po prostu zwalczam takie sytuacje [...]. Myślę, że w jakimś stopniu to mnie zmotywowało, ta sytuacja cała, najpierw moja, a później tych wszystkich ludzi dookoła, żeby wziąć się za siebie, żebym ja był na tyle silny, żebym mógł obronić siebie i obronić kogoś (Ł., I rok studiów).

Z innej strony, przywoływanie przeszłych negatywnych doświadczeń i odczuwane przez obserwatorów emocje, takie jak niepokój czy strach przed ponownym dręczeniem, są powodem obawy przed kolejnym „wtłoczeniem” w rolę ofiary. To z kolei hamuje interwencję, mimo świadomości wykluczania z grupy i poczucia wyrządzanej innym krzywdy. Jedna z osób badanych wyjaśnia:

Miałam w myślach, że powinnam (stanąć w obronie), ale z drugiej strony się bałam też, że później na mnie to przejdzie (J., II rok studiów uz.).

Każdy przejaw obserwowania to jest ryzyko, ryzyko tego, że ja z obserwatora też stanę się ofiarą, że moja bezpieczna, neutralna pozycja, że ona się zmieni, że dołączę do tych ludzi, którzy są dręczeni (M., I rok studiów). 
By poradzić sobie z odczuwanym dyskomfortem, badani wskazali także pewnego rodzaju satysfakcję, ulgę, jaką odczuwali, kiedy to nie oni, tylko ktoś inny padł ofiarą dręczenia. Jedna z osób badanych wyjaśnia:

Może ja się ucieszyłam, że nie padło na mnie, ja jestem dosyć osobą taką wrażliwą [...] takiego słabego charakteru i wiedziałam, że no nie mogłam pomóc drugiej osobie sama. [...] ja raczej nie reagowałam na takie rzeczy, tylko co najwyżej cieszyłam się, że nie padło na mnie (K., II rok studiów uz.).

Osoby badane wskazują, że identyfikacja z grupą ofiar hamuje ich działania. Trudno jest sobie poradzić z piętnem ofiary, a jeszcze trudniej stanąć w obronie innych. Badany student podkreśla, że będąc w grupie ofiar, poszczególni jej członkowie wzmacniają siebie nawzajem w zaniechaniu interwencji, w wyniku czego nie sprzeciwiają się dręczeniu:

Identyfikowałem się z tą grupą uciśnionych [...]. Moja niemoc i niemoc innych, jakbyśmy się nakręcali, że po prostu nie możemy nic zrobić [...] ta nić porozumienia osłabiała jakby nas, że byliśmy mniej zdolni do tego, żeby zareagować (Ł, I rok studiów).

\subsection{EMPATIA}

Ważnym czynnikiem powodującym poczucie dyskomfortu świadków podczas obserwowania dręczenia jest przyjmowanie perspektywy ofiary oraz współodczuwanie z nią. Na podstawie wypowiedzi badanych można wnioskować, iż owa wrażliwość empatyczna jest warunkowana wcześniejszymi doświadczeniami badanych w roli ofiary.

Wiedziałem, co czują ci ludzie, jakie jest to uczucie, jak się wraca do domu i jest się samemu, załóżmy ze swoimi problemami, kiedy się nie chce chodzić do szkoły przez tych ludzi [...] ja się źle czułem, że oni siebie nie mogą obronić (Ł, I rok studiów).

Próbowałam się postawić w sytuacji tego chłopaka gnębionego, nie chciałabym, żeby ktoś się tak w stosunku do mnie zachowywał, że na pewno jest mu przykro (A., I rok studiów).

Nie chciałam patrzeć, jak ona cierpi, zawsze próbowałam ją wesprzeć (K., II rok studiów uz.). 
Inny student podaje, iż wie jakie odczucia mają ofiary i to go mobilizuje do obrony.

\subsection{GRANICE NORM MORALNYCH}

Ważną kategorią są normy moralne, jakie mają świadkowie. Rozumiane są one jako standardy, pożadane i niewłaściwe wzorce zachowań pożądanych i niewłaściwych w konkretnej sytuacji. Jeśli świadek obserwując sytuację, w której ofiarę doprowadza się do płaczu, ma poczucie wyrządzanej jej krzywdy, a to zachowanie nie mieści się w obszarze jego norm, to jest skłonny zareagować. Jedna z badanych podała:

Jak ktoś kogoś doprowadza do płaczu, to nie są żarty. [...] nie żeby dziewczynę codziennie popychać albo zabierać jej plecak. Nie uważam, że to były jakieś żarty (K., II rok studiów).

Obecnie z uwagi na przesunięcie granic norm moralnych pewne zachowania (w tym dręczenie) nie budzą już większego zdziwienia i sprzeciwu wśród obserwatorów. Dręczenie rówieśnicze często odbierane jest jako naturalny element środowiska rówieśniczego. Zdarza się, że jest on traktowany jako dobra zabawa, powód do śmiechu czy naturalne zachowanie uczniów. Można tu mówić o neutralizacji dręczenia, które występuje w środowisku szkolnym, jest akceptowane przez znaczną część uczniów i mieszczące się w granicach ich norm grupowych. Uczniowie obserwują zachowania bullyingowe, jednak przyzwyczajają się do nich.

Każdy, kto chodził do szkoły, padł ofiarą wyśmiewania, złośliwości, no bo tak to jest w szkole (Ł., I rok studiów).

Mogliśmy się śmiać z jakiejś osoby, ale to było w formie takich żartów. Ci uczniowie mieli dużą uciechę, że zabawiają się kosztem drugiego, a on na przykład krzyczy, sprzeciwia się temu i nie traktuje tego jako żarty. [...] Ale w zasadzie temu uczniowi nie działa się krzywda, nikt go fizycznie nie krzywdził, nie bił, krew nikomu nie leciała, tylko to było w formie żartów (K, II rok studiów uz.). 


\subsection{BLISKIE RELACJE Z OFIARĄ DRĘCZENIA}

Badani w swoich wypowiedziach podkreślali także znaczenie więzi łączącej ich z ofiarami lub sprawcami. Bliska, przyjacielska więź z ofiarą może mobilizować do działania obronnego. Jedna z badanych wyjaśnia:

Zostałam z nią, powiedziałam parę słów pocieszenia, byłam wsparciem, nie odeszłam [...] to była bliska mi osoba [...]. To była specyficzna sytuacja, bo to była moja najbliższa przyjaciółka (J., II rok studiów uz.).

Co więcej - ważnym motywatorem do działań obronnych jest także bliska więź ze sprawcą. Jeden z badanych studentów twierdzi, że bliskie relacje ze sprawcą mogą także stanowić motywację do wyrażenia otwartego sprzeciwu w sytuacji dręczenia:

Myślę, że jeśli się przyjaźniłam z jakimiś osobami, to znaczy często było tak, że na przykład agresor rozmawiał ze mną na ten temat i faktycznie wyciągał z tego jakieś wnioski, kiedy ja próbowałam cokolwiek wytłumaczyć, że jego zachowanie jest złe, to wtedy ta agresja się zmniejszała (B., II rok studiów uz.).

\subsection{POCZUCIE WŁASNEJ SKUTECZNOŚCI}

Poczucie własnej skuteczności to kolejny istotny motywator do podjęcia działań interwencyjnych. Świadkowie twierdzili bowiem, że jeśli mają przekonanie, że są w stanie pomóc ofierze, mobilizowało ich to do podejmowania interwencji.

Jeżeli widziałem cień szansy, że po prostu można coś spróbować zrobić, to próbowałem to robić (Ł., I rok studiów).

Część badanych ocenia skuteczność własnej interwencji przez pryzmat osobistej sytuacji społecznej. Badani twierdzą, że skoro nie byliby w stanie siebie obronić, to trudno im będzie stanąć w obronie innych.

Ja nie pamiętam [...], a nawet nie potrafiłabym [...], nie wiedziałabym, jak ją obronić [...] nie, żebym się bała, że mi coś zrobią, nie żebym nie miała argumentów, żeby kogoś bronić, bo sama się czułam jakoś, sama też nie potrafiłabym siebie obronić (B., III rok studiów). 
Chociaż bardzo jej współczułam i też chciałam jej pomoc, to nie wiedziałam, jak (K., II rok studiów).

\section{PODSUMOWANIE}

Na podstawie badań własnych można wysnuć wniosek, że pewne zachowania i postawy świadków w sytuacji dręczenia przyczyniają się do wzmocnienia lub osłabienia dręczenia szkolnego. Brak interwencji świadków wyklucza bowiem osobę dręczoną ze środowiska rówieśniczego i przyczynia się do wzmocnienia jej wiktymizacji. Na drugim biegunie (choć w znaczącej mniejszości) znajdują się jednak świadkowie sprzyjający ponownemu włączaniu ofiar do grupy społecznej, którzy poprzez własne interwencje (przejawiające się w formie wsparcia, otwartej obrony, rozmowy ze sprawcą) przyczyniają się do minimalizowania aktów dręczenia rówieśniczego.

Założeniem badań była identyfikacja czynników mobilizujących uczestników dręczenia rówieśniczego do podjęcia interwencji. Zaprezentowane wyniki badań korespondują z danymi badaczy podejmujących problematykę bullyingu.

Wypowiedzi badanych wskazują, iż znaczącym czynnikiem motywującym do obrony ofiar jest empatia, zarówno emocjonalna, jak i poznawcza. Autorzy podają, że obrońcy ofiar charakteryzują się wyższym poziomem empatii, który pozwala im dostrzec cierpienie ofiar i podjąć działania prospołeczne, takie jak bezpośrednia rozmowa ze sprawcą, opowiadanie się po stronie ofiary. Jednakże mimo że empatia jest istotnym czynnikiem skorelowanym z działaniami prospołecznymi, to jednak nie jest ona wystarczająca, by podjąć obronę, jeśli pojawiają się inne zmienne, hamujące działania pomocowe (Gini, Albiero, Benelli, Altoe, 2008; Thornberg). Ponadto wśród predyktorów interwencji wymieniali także wysokie poczucie skuteczności, rozumiane jako przekonanie, że są w stanie podjąć działania, które zapobiegną dręczeniu (Pöyhönen, Jovonen, Salmivalli, 2012;Thornberg, Jungert, 2013). Okazuje się, że podjęcie aktywnego działania wymaga przekonania, iż świadek osiągnie zamierzony cel. Świadkowie charakteryzujący się natomiast niskim poziomem skuteczności przyjmują postawy asystujące lub unikające sytuacji bullyingowych. Badania własne potwierdzają wcześniejsze doniesienia, ale także wskazują na ważną zmienną, jaką jest wiedza dotycząca ewentualnych sposobów skutecznej interwencji. Można bowiem przypuszczać, iż uczestnicy bullyingu często nie mają pomysłu na to, w jaki sposób mogliby pomóc ofierze, ale też nie mają przekonania, że ich działanie przyniesie oczekiwany efekt (por. Forsbeg, Wood, Smith, Varjas, Mayers, Jungert, Thornberg, 2016). 
Bliskie relacje z ofiarą to kolejny istotny predyktor interwencji. Badania wskazywali na istotną rolę przyjaźni jako czynnika mobilizującego do obrony ofiar. W wypowiedziach wspominali zarówno o więzi, jaka łączy ich z ofiarą, jak i o relacjach, jakie mają ze sprawcą. Dzięki bliskiej więzi ze sprawcami świadkowie nie mają obaw i nie odczuwają strachu przed jawnym okazaniem sprzeciwu. Z drugiej strony nie wyrażają zgody na obserwowanie krzywdy osoby bliskiej i stają w obronie ofiary. Podobne wnioski prezentują w swoich badaniach Oh i Hazler (2009; za Meter, Card, 2015). Podczas retrospektywnych wywiadów z uczestnikami bullyingu zapytali respondentów o bliską więź, jaka łączy ich z ofiarą i sprawcą. Okazało się, że świadkowie byli bardziej skłonni do podjęcia interwencji, gdy ofiara była im bliska. Odmienne wnioski prezentują odnośnie do relacji obserwatorów ze sprawcami. Jak podają, świadkowie nie reagowali na bullying, gdy byli w bliższej relacji ze sprawcą, a szczególnie gdy jego pozycja w hierarchii grupy była wysoka. Ponadto dowiedli, że brak bliskiej więzi z ofiarą i sprawcą także wyklucza podejmowanie działań interwencyjnych.

Przedstawione w artykule wnioski są częścią większego projektu badawczego, jednak korespondują z wynikami innych badaczy problemu. W wyniku analizy materiału empirycznego pozyskanego w wyniku badań własnych oraz zgromadzonego przez innych badaczy można wnioskować, że istnieje wiele predyktorów uruchamiających interwencję podczas dręczenia rówieśniczego. Jednak wśród istotnych zmiennych, które warto wziąć pod uwagę, planując oddziaływania profilaktyczne, są: poziom empatii, poczucie skuteczności, bliskie relacje z ofiarą oraz normy moralne świadków.

\section{Bibliografia}

Caravita, S.C.S., Di Blasio, P., Salmivalli, Ch. (2009). Unique and Interactive Effects of Empathy and Social Status on Involvement in Bullying. Social Development, 18, s. $140-163$.

Creswell, J.W. (2013). Projektowanie badań naukowych. Metody jakościowe, ilościowe i mieszane. Kraków: Wydawnictwo Uniwersytetu Jagiellońskiego.

Eliot, M., Cornel, D., Gregory, A., Fan, X. (2010). Supportive school climate and student willingness to seek help for bullying and threats of violence. Journal of School Psychology, 48, s. 533-553.

Forsbeg, C., Wood, L., Smith, J., Varjas, K., Meyers, J., Jungert, T., Thornberg, R. (2016). Students Views of Factors Affecting their Bystander Behaviours in Response to school Bullying: a cross-collaborative conceptual, qualitative analysis. Research Paper in Education, 33, s. 127-142. 
Gini, G., Albiero, P., Benelli, B., Altoe, G. (2007). Does empathy predict adolescents bullying and defending behavior? Aggressive Behavior, 33, 467-476.

Gini, G., Albiero, P., Benelli, B., Altoe, G. (2008). Determinants of Adolescents Active Defending and Passive Bystanding Behavior in Bullying. Journal of Adolescence, 31, s. 93-105.

Jenkins, J., Nickerson, A. (2016). Bullying Participant Roles and Gender as Predictors of Bystander Intervention. Aggressive Behavior, 9999, s. 1-10.

Kawalec P., (2014). Metody mieszane w kontekście procesu badawczego w naukoznawstwie. Zagadnienia Naukoznawstwa, 1(199), s. 1-20.

Komendant-Brodowska, A. (2009). Grzech zaniechania. Świadkowie przemocy szkolnej w perspektywie teorii gier. Decyzje, 11, s. 5-47.

Komendant-Brodowska, A. (2012). Grupowe uwarunkowania przemocy szkolnej. Rozprawa doktorska. Warszawa: Warszawski Wydział Filozofii i Socjologii. Pobrane z: http:// docplayer.pl/5883848-Grupowe-uwarunkowania-przemocy-szkolnej.html.

Locke, L.F., Spirduoso, W.W., Silverman, S.J. (2007). Proposal that work: a guide for planning dissertations ang grant proposals. Thousand Oaks, CA: Sage.

Meter, D., Card Noel A. (2015). Defenders of victims of peer aggression: Interdependence theory and an exploration of individual, interpersonal, and contextual effects on the defender participant role. Development Review, 38, s. 222-240.

Miński, R. (2017). Wywiad pogłębiony jako technika badawcza. Możliwości wykorzystania IDI w badaniach ewaluacyjnych. Przegląd Socjologii Jakościowej. 13(3), s. 30-51.

Olweus D., (2003). A Profile of Bullying at School. Educational Leadership, 60, s. 12-17.

Padgett, P., Notar, Ch. (2013). Bystanders are the Key to Stopping Bullying. Universal Journal of Educational Research, 1(2), s. 33-41.

Pöyhönen, V., Jovonen, J., Salmivalli, Ch. (2012) Standing up for the Victim, Siding with the Bully or Standing by? Bystander Responses in Bullying Situations. Social Development, 21(4), s. 722-741.

Pronk J., Goossens F.A., Olthof T., De Mey L., Willemen A.M. (2013). Children's intervention strategies in situations of victimization by bullying: social cognitions of outsiders versus defenders. Journal of School Psychology, 51(6), s. 669-682.

Raport NIK Przeciwdziałanie zjawiskom patologii wśród dzieci i młodzieży szkolnej (2013). Pobrane z: https://www.nik.gov.pl/plik/id,6956,vp,8803.pdf.

Ryszewska-Banko, J. (2017). Ekskluzja społeczna w klasie szkolnej w opiniach gimnazjalistów. W: A. Szczurek-Boruta, K. Jas. (red.), Człowiek wykluczony i człowiek w sytuacji zagrożenia wykluczeniem społecznym edukacyjnym kulturowym wyzwania powinności pedagogiki zadania (s. 103-112). Toruń: Wydawnictwo Adam Marszałek.

Saarento, S., Kärnä, A., Hodges, E.V.E., Salmivalli, Ch. (2013). Student - classroom - and school-levelrisk factors for victimization. Journal of School Psychology, 51, s. 421-434.

Sainio, M., Veenstra, R., Huitsing, G., Salmivalli, Ch. (2011). Victims and their defenders: A dyadicapproach. International Journal of Behavioral Development, 35, s. 144-151.

Sallmivalli, Ch. (2010). Bullying and the peer group: A review. Agression nad Violent Behaviour, 15, s. 112-120. 
Salmivalli, Ch. (2014). Participant Roles in Bullying: How Can Peer Bystanders Be Utilized in Interventions? Theory Into Practice, 53, s. 286-292.

Thornberg, R., Tenenbaum, L., Varjas, K., Meyers, J., Jungert, T., Vanegas, G. (2012). Bystander Motivation in Bullying Incidents: To Intervene or Not to Intervene? Western Journal of Emergency Medicine, XIII(3), s. 247-252.

Thornberg R., Jungert T. (2013). Bystander Behaviour in Bullying Situations: Basic moral Sensitivity, Moral Disangagement and Self-efficacy. Journal of Adolescence, 36(3), pp. 475-483.

Thornberg R., Jungert T. (2017). Bystander Behaviour in bullying Situations. Basic Moral Sensitivity, Moral Disengagement and Defender Self-Efficacy. Journal of School Psychology, 63, s. 49-62.

Tłuściak-Deliowska, A. (2013). Deklaracje postaw wobec przemocy rówieśniczej wśród gimnazjalistów. Psychologia Rozwojowa, 8(3), s. 75-86.

Tłuściak-Deliowska, A. (2015). Interwencje rówieśników w sytuacji dręczenia szkolnego. Rola czynników kontekstowych. Implikacje praktyczne. Studia Edukacyjne, 32, s. 303-320.

Wilczyńska, A. (2013). Uwarunkowania Radzenia sobie młodzieży w sytuacjach zagrożenia wykluczeniem społecznym. Katowice: Wydawnictwo Uniwersytetu Śląskiego.

Wilczyńska, A. (red.). (2014). Młodzież na biegunach życia społecznego. Warszawa: PWN. Wójcik, M., Hełka A., Kozak B., Błońska M., Garbaciuk A., Małczak. M. (2015). Zapobieganie wykluczeniu rówieśniczemu w gimnazjum. Edukacja, 3(134), s. 123-140. 